\title{
Reproduction in agouti (Dasyprocta spp.): A review of reproductive physiology for developing assisted reproductive techniques
}

\author{
Érica Camila Gurgel Praxedes, Gislayne Christianne Xavier Peixoto, Andréia Maria da Silva, \\ Alexandre Rodrigues Silva ${ }^{\mathfrak{f}}$
}

Laboratory on Animal Germplasm Conservation, Universidade Federal Rural do Semi Árido (UFERSA), BR 110, Km 47, Costa and Silva, Mossoró, RN, Brazil.

\begin{abstract}
Dasyprocta spp. (agouti) include wild rodents with highlighted ecological and economic importance, and are considered experimental models for endangered hystricognath rodents. Of late, development of techniques to conserve their genetic material as well as the formation of biobanks is increasing. In this context, this review describes the main advances in the knowledge of the reproductive morphophysiological specificities of agouti as well as the development and improvement of assisted reproductive techniques aimed at conservation, multiplication, and exploitation of their reproductive potential under captivity.
\end{abstract}

Keywords: biobank, rodentia, wildlife.

\section{Introduction}

Rodents account for the largest order of mammals in the world and are found in the most varied types of habitats (Emmons and Feer, 1997). Of these, agouti (Fig. 1), a hystricognath rodent, Dasyprocta spp. or Dasyprocta aguti, is found throughout the area of Neotropical America and is distributed into 13 different species that constitute the genus Dasyprocta (IUCN, 2018).

Agouti is currently suggested as an experimental model for other species of hystricognath rodents that are vulnerable to extinction (Costa and Martins, 2008) because they can easily adapt to captivity and, thus, exhibit prolificity, precocity, and relatively short gestation period (Hosken and Silveira, 2001). These characteristics facilitate studying their physiology and exploring their zootechnical potential (Pachaly et al., 1999; Ribeiro et al., 2008).

Owing to their diverse and substantial distribution, these wild rodents represent an important protein source for human consumption (Lopes et al., 2004) as well as for obtaining skin, leather, and bristle (Silva et al., 2010). Moreover, they are important seed dispersers and maintain the ecological balance (Silva et al., 2013).

Still, with their economic and ecological relevance, agouti present a potential market that justifies the research focused on its conservation (Souza et al., 2003) to improve reproduction management of the commercial breed (Bonaudo et al., 2005). In this context, this review describes the main advances in research on the reproductive morphophysiological specificities of agouti as well as the development and improvement of assisted reproductive techniques (ART) aimed at conservation, multiplication, and exploitation of their reproductive potential under captivity.

\section{General characteristics of male and female agouti}

The term agouti, also called Dasyprocta spp., refers to the third largest frugivorous rodent (Henry, 1999). The Dasyprocta genus comprises approximately 13 species of agouti, viz., $D$. azarae, $D$. coibae, $D$. croconota, D. fuliginosa, D. guamara, D. iacki, D. kalinowskii, D. leporina, D. mexicana, D. prymnolopha, D. punctata, D. ruatanica, and D. variegata (IUCN, 2018). The main differences found between these species are related to coat coloration and their conservation status (IUCN, 2018; Table 1). However, some species are not easily recognizable owing to taxonomic limitations and absence of any modern taxonomic revision (Emmons and Feer, 1997). Cytogenetic studies are essential because each species is characterized by a typical karyotype, which may differ from others with respect to form, size, and number of chromosomes (Lima, 2000). By cytogenetic analysis of 30 animals of the genus Dasyprocta (D. prymnolopha, D. leporina, and D. fuliginosa), Ramos et al. (2003) identified that the individuals presented two cellular lineages, with $2 n=64$ and $2 n=65$ chromosomes. The karyotypes showed similarity, and chromosomal polymorphism was not detected by Giemsa conventional staining and $\mathrm{G}$ banding. All analyzed specimens presented a diploid number of 64 or 65 chromosomes. This variation was observed with a frequency of approximately $70 \%$ in cells with $2 n=64$ and $30 \%$ in cells with $2 n=65$. There was no variation in the pattern of nucleolus organizer regions (NORs) in the species studied, which was used to verify chromosomal polymorphism (Ramos et al., 2003).

Agouti are distributed over a wide area of Neotropical America and are found in a great diversity of habitats from the south of Mexico, through Central America, to Argentina, Uruguay, and Paraguay (Deutsch and Puglia, 1988). They exhibit an extraordinary variety of ecological adaptations, supporting existence in the coldest and more torrid climates. They can thrive in regions with the highest floristic cover at high altitudes (Emmons and Feer, 1997).

Agouti are medium-sized animals, weighing between 2 and $5 \mathrm{~kg}$, with an average height of $23 \mathrm{~cm}$ 
and length of $50 \mathrm{~cm}$, measured from the muzzle to the base of the tail, with the tail being generally bristle. The head and thorax show fur colors ranging from gray to bright orange covered by long, harsh, and strong pelage, with predominating brown and light or dark yellowish or golden colors. The top of the head, neck, and middle of the back between the shoulders are sometimes dark with long bristles; the ears are small and bare, similar to the tail that is almost vestigial (Smythe, 1987; Emmons and Feer, 1997). In addition, they possess four long and curved incisor teeth, whose macroscopic characteristics reveal structure similar to that of other mammals (Oliveira et al., 2012). Between males and females there is no sexual dimorphism; therefore, to differentiate them, it is necessary to perform sexing through palpation, where the difference between the male's prominent penis and the female's two vaginal folds, forming the vulva, is easily observed (Guimarães et al., 2009).

These animals have adapted to terrestrial life by a reduction in functional fingers and a vestigial thumb, with four digits on the forelimbs and three on the hindlimbs. Furthermore, the claws of the forelimbs are slightly arched, indicating the ability to excavate, although they are not true diggers. The hindlimbs are much larger than forelimbs, enabling them to jump (Oliveira et al., 2012).

These animals have diurnal and crepuscular habits, and when threatened, they may present nocturnal habits. They are naturally herbivorous feeding on leaves, roots, flowers, fungi, seeds, and, particularly fruits found in the soil (Santos et al., 2005). In case of fruit shortage, agouti spend less time resting and more time foraging, looking for seeds that have been buried previously (Smythe, 1987). Such behavior of digging, hiding, and seeking, also observed in Myoprocta spp., is essential for the dispersion of plant species (Forget and Milleron, 1991). Thus, agouti act on aggregate distribution of tree seeds that is secondary to the action of long-distance dispersal animals, such as tapirs (Tapirus terrestris) (Lange and Schmidt, 2007). These species are also important links in the food chain because they are prey to birds, snakes, and wild carnivores, thereby maintaining the environmental balance (Hosken and Silveira, 2001). In addition, agouti are economically important because they enable the commercialization of skin, leather, and bristle (Silva et al., 2010). Yet, to their economic and ecological importance, because of their stable world population, they can be used as experimental models for endangered agouti, such as $D$. ruatanica, D. coibae, and $D$. mexicana (IUCN, 2018).

Because they are considered as important protein sources, agouti have been used for human consumption. Their meat is white, rich in nutrients, soft, tasty, and an excellent source of calcium and phosphorus, with low caloric value (each $100 \mathrm{~g}$ of meat has approximately $120 \mathrm{Kcal}$ ) (Barbosa, 2010). The commercialization of agouti meat provides low market value, requiring little manpower. The system of fattening and development of matrices are two activities that can be practiced at the same time, potentiating producer profit. According to some researchers, the meat of these animals is as appreciated as paca meat, the most sought-after in the market among the wild species (Barbosa, 2010). For example, in Trinidad and Tobago, and Central America, agouti meat is considered a spice; therefore, this animal has been intensively hunted (Roopchand, 2002).

Breeding agouti under captivity is an alternative for its preservation in the natural habitat and allows the exploration of their zootechnical potential, thereby allowing studies on their physiological characteristics (Pachaly et al., 1999; Lopes et al., 2004). However, studies with the appropriate methods of productive and reproductive management of wild animals are limited, which could reflect in higher productivity, enabling the preservation of some species by reduction in predatory hunting (Lopes et al., 2004).

Hence, it is necessary to apply captive breeding programs and ART as tools to ensure the increase in their reproductive potential and conservation of their genetic material (Comizzoli et al., 2001), allowing the increase in their zootechnical potential and genetic variability; thus, enabling the study of their physiological characteristics.

Table 1. Main differences among agouti's species (Dasyprocta spp.)

\begin{tabular}{lll}
\hline Species & Coats & Conservation status \\
\hline Dasyprocta azarae & Black or white or pale orange & Listed as potentially vulnerable in Argentina \\
Dasyprocta coibae & Cream or black & Vulnerable \\
Dasyprocta leporina & Red-rumped & Estable \\
Dasyprocta iacki & - & Insufficient data \\
Dasyprocta guamara & Dark & Near threatened \\
Dasyprocta kalinowskii & - & Insufficient data \\
Dasyprocta croconota & - & Insufficient data \\
Dasyprocta fuliginosa & Black & Least Concern \\
Dasyprocta mexicana & Mexican Black & Critically Endangered \\
Dasyprocta prymnolopha & Black-rumped & Least Concern \\
Dasyprocta punctata & Uniform reddish brown & Least Concern \\
Dasyprocta ruatanica & Black or Cream & Endangered \\
Dasyprocta variegata & Brown & Insufficient data \\
\hline Source: & &
\end{tabular}

Source: IUCN, 2018. 


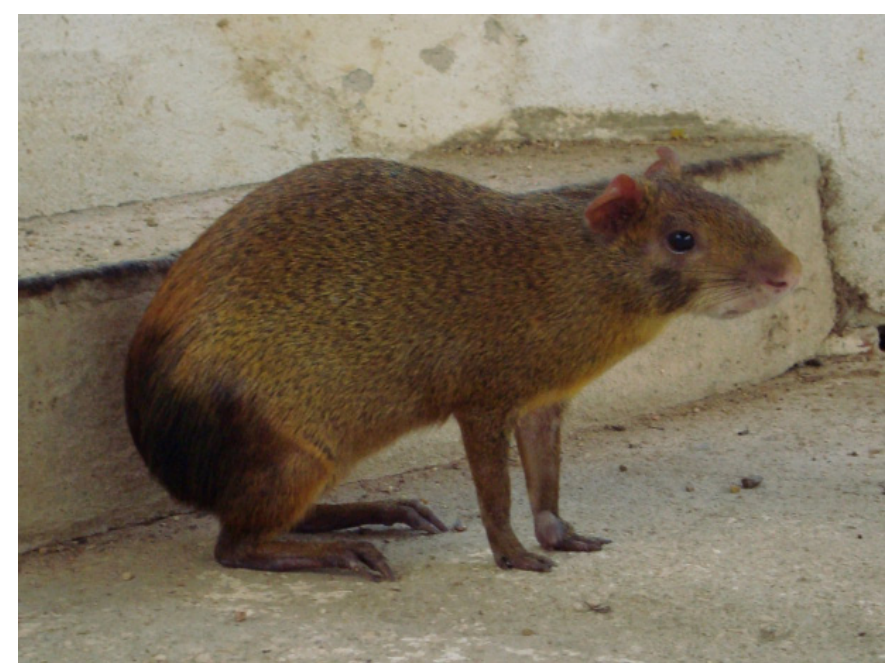

Figure1. A red-rumped agouti (Dasyprocta leporina) specimen.

\section{Reproductive morphophysiological characteristics of male agouti}

In agouti, the internal reproductive system is composed of accessory glands (vesicular glands, prostate, and bulbourethral glands), testis, and epididymis (delimited by adipose tissue, i.e., caput epididymal) that are paired and fully coated by cremaster muscle, allowing a greater range of movement and internalization of the testicle in the abdomen (Paula and Walker, 2012). In addition, the epididymis of Dasyprocta spp. is composed of principal, basal, halogen, apical, and clean cells with pseudostratified, columnar, and stereociliated epithelium (Arroyo et al., 2014).

According to Mollineau et al. (2006) in D. leporina, the testicular length, diameter, and weight are $3.67 \pm 0.12 \mathrm{~cm}, 1.67 \pm 0.04 \mathrm{~cm}$, and $5.03 \pm 0.52 \mathrm{~g}$, respectively. In addition, the ductus deferens has a length of $10.98 \pm 0.40 \mathrm{~cm}$ and mean diameter of $0.14 \pm 0.01 \mathrm{~cm}$. The absence of a scrotum, a characteristic observed in agouti, has been reported by Menezes et al. (2003).

The penis (Fig. 2) is doubled caudally with a Ubend lying down, with a mean length of $9.90 \pm 0.43 \mathrm{~cm}$, and contains paired ventral keratinous spicules. It is observed that the glans penis presents a rounded dilation, called urethral torus or penile flower, at the time of erection (Carvalho et al., 2008; Mollineau et al., 2012). Four steps are documented in the erection process: stage 1, protrusion of the penis from the preputial orifice; stage 2, opening of the lateral cartilages of the penis; stage 3, flowering of the head of the glans penile flower, eversion of the intromitting bag, and protrusion of the keratinous spicules; and stage 4, protrusion of the keratinous spurs and ejaculation (Mollineau et al., 2012).

Regarding reproductive development in males, Costa et al. (2010) observed that the spermatogenic cycle lasts for $9.5 \pm 0.03$ days, and the total duration of spermatogenesis is $42.8 \pm 0.16$ days. According to Assis
Neto et al. (2003a), the period from birth to five months comprises the pre-pubertal period, in which the presence of gonocytes is observed with the absence of tubular lumen in the testicular cords as well as the presence of spermatogonia, spermatocytes, spermatids, Sertoli and Leydig cells (Arroyo et al., 2017); from six to eight months of age is the transition phase (pre-puberty to puberty), in which $40 \%$ to $90 \%$ of the testicular cords are in the process of tubular lumination, coinciding with the appearance of the first primary spermatocytes and rounded spermatids. Puberty in male agouti is established at around the age of nine months, where it is possible to observe the presence of all cell types and spermatozoa in the testicular lumen after eight stages of the cycle of the seminiferous epithelium (Assis Neto et al., 2003b). According to Arroyo et al., (2017), the main changes in the testis of agouti (Dasyprocta spp.) occur between the prepubescent and prepubertal periods, when the germinal epithelial organization occurs and the Sertoli cells undergo morphological and functional changes to form the spermatozoa.

Morphological analysis of agouti (Dasyprocta spp.) sperm demonstrated that these cells present an oval-shaped head, like a shovel with a rounded head apex, and a flat base (Fig. 3). Sperm head is tapered, without prominence of the acrosome or evidence of the perforatorium (Arroyo et al., 2017). Likewise, it has been reported that the base of the head is symmetric and the tail is extended and sharpened (Mollineau et al., 2006; Ferraz et al., 2009). Regarding the morphometry, the sperm presented distinct results among species, $48.0 \pm 0.3 \mu \mathrm{m}$ and $40.12 \pm 2.4 \mu \mathrm{m}$ for the species D. leporina and D. prymnolopha, respectively (Mollineau et al., 2008; Ferraz et al., 2011).

In this context, in wild animals, it is necessary to determine the anatomy and physiology of the species before implementing ART, to adapt to the characteristics of each species. Further, it is often necessary to perform tests of interaction between different factors that may affect the success of the technique. 


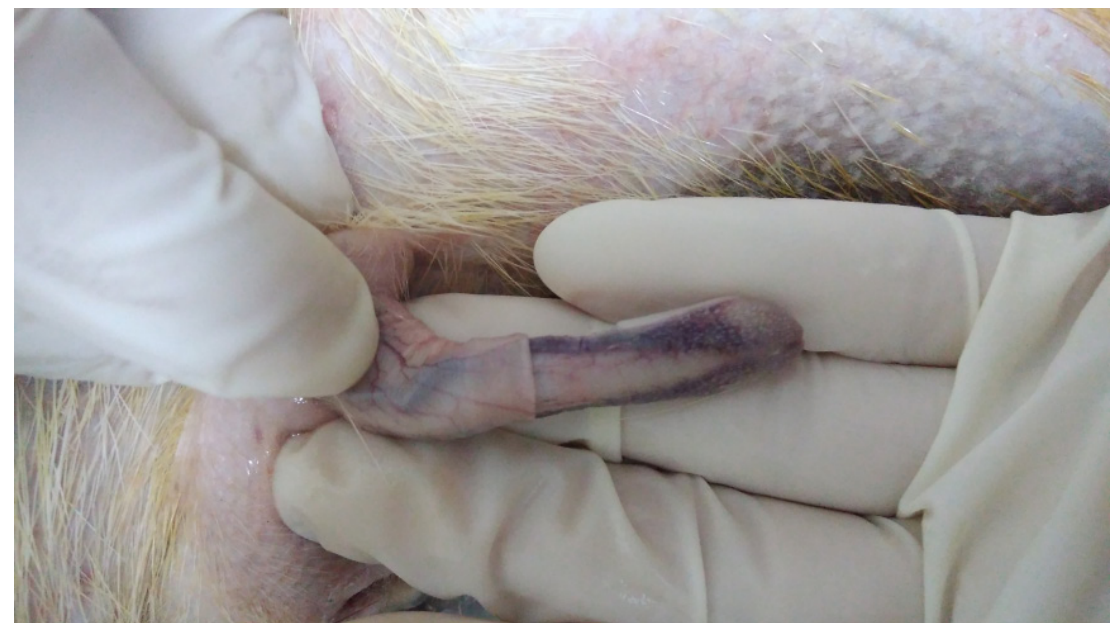

Figure 2. Agouti's (Dasyprocta leporina) penis with prepuce partly removed.

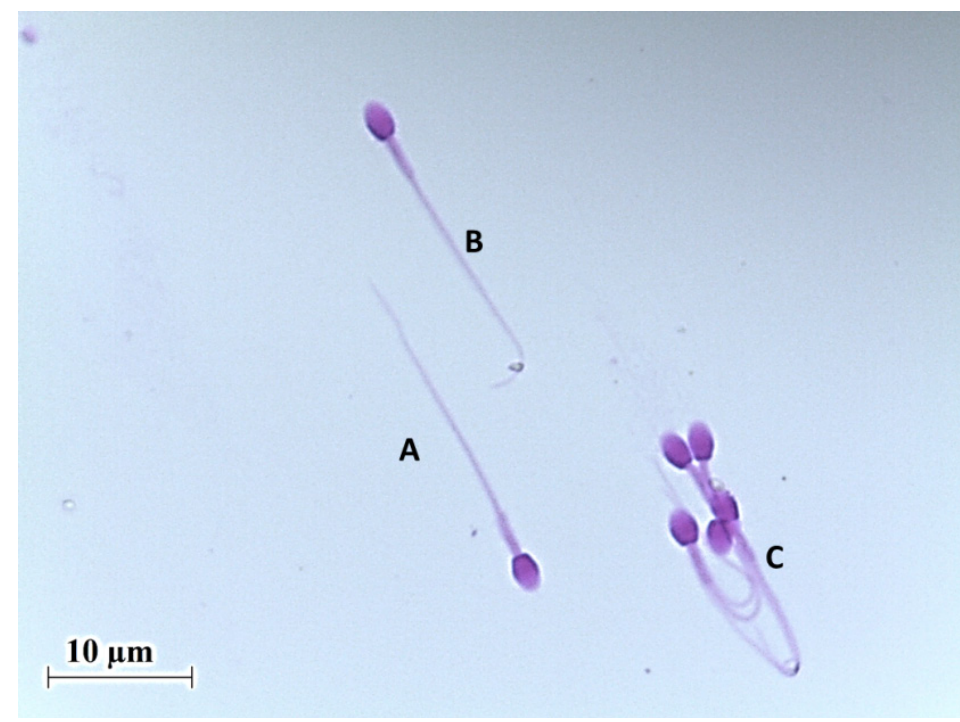

Figure 3. Morphology of agouti's (Dasyprocta leporina) epididymal sperm stained with Bengal rose. (A) Normal spermatozoa; (B) abnormal spermatozoa with tail folded; (C) abnormal spermatozoa with high tail folded.

\section{ART for male agouti}

Application of ART as an initial step for developing methods for sperm recovery is required. Of late, methods for obtaining spermatozoa by retrograde epididymal washing (Ferraz et al., 2011; Silva et al., 2011, 2012; Castelo et al., 2015) or electroejaculation (Mollineau et al., 2008; Martinez et al., 2013; Castelo et al., 2016) have been described for agouti.

Obtaining epididymal spermatozoa offers the possibility of acquiring and using the genetic material immediately after the animal's death (Goovaerts et al., 2006) because the genetic material is morphologically viable with a suitable degree of maturity and fertilizing capacity (Monteiro et al., 2011). There are two basic methods for obtaining spermatozoa from the epididymis, viz., retrograde washing and flotation. The most used method is retrograde washing (MartinezPastor et al., 2006). This method consists of injecting an aqueous medium followed by tail cutting, in the direction from the ductus deferens to the tail epididymis, for the recovery of sperm (Comizzoli et al., 2001). In agouti, Ferraz et al. (2011) were the first to demonstrate the possibility of obtaining spermatozoa by means of retrograde washing in animals previously submitted to orchiectomy, and they obtained a concentration of $748 \pm$ 418.66 spermatozoa $/ \mathrm{mL}$. Subsequently, the technique was applied in the same species of agouti by Silva et al. $(2011,2012)$, in which a volume of $300 \pm 2 \mu \mathrm{L}$ was recovered with a concentration of $1.4 \pm 0.3 \times 10^{9}$ spermatozoa $/ \mathrm{mL}$. Using the same method in D. leporina, Castelo et al. (2015) were able to recover a total volume of $1.65 \pm 0.22 \mathrm{~mL}$ with a concentration of $1.04 \pm 0.2 \times$ $10^{6}$ spermatozoa $/ \mathrm{mL}$. 
Electroejaculation is another efficient way of obtaining sperm, primarily because the death of the animal is not necessary. This method of semen collection is based on the induction of ejaculatory reflex through the application of electrical stimuli on the nerve plexus located in the pelvic floor of the animal. A lubricated transrectal probe connected to an electrical stimulator is introduced in the rectum of the animal under anesthesia or without anesthesia to achieve stimuli (Silva et al., 2004). Mollineau et al. (2008) were the first to describe the use of electroejaculation in $D$. leporina using ketamine as an anesthetic; they applied a charge of $6 \mathrm{~V}$ for $5 \mathrm{~s}$ followed by increasing the charge by $1 \mathrm{~V}$ until $12 \mathrm{~V}$ with $5 \mathrm{~s}$ intervals of rest. Thus, the authors obtained an efficiency of $30 \%$ of ejaculates containing spermatozoa. In a subsequent study using the same electroejaculation protocol, but starting at $2 \mathrm{~V}$, an efficiency of $40 \%$ of ejaculates containing spermatozoa was obtained (Mollineau et al., 2010a). Additionally, Castelo et al. (2016) demonstrated the interaction between different types of electrical stimuli, as sine or quadratic waves, and electroejaculation using ring or strip electrode apparatus with better results than those reported by Mollineau et al. $(2008,2010)$. The authors obtained $70 \%$ of ejaculates, with $57 \%$ of ejaculates containing spermatozoa, when using the protocol with the ring electrode associated with sinusoidal stimuli (Castelo et al., 2016). However, Martinez et al. (2013) obtained better results using four brown agouti $(D$. azarae) and obtained $100 \%$ success in semen collection. For this, the authors used an association of azaperone and meperidine as preanesthetic medication. Afterwards, the animals were anesthetized with the combination of ketamine and xylazine, followed by lumbosaccharide application of lidocaine. The protocol of stimulation comprised four sets of 20 electrostimulations for $3 \mathrm{~s}$ each with $2,4,6$, and $8 \mathrm{~V}$, with a 2-min interval between each series. The results of evaluation of sperm characteristics obtained from such experiments are shown in Table 2.

With respect to the development of preservative protocols, Silva et al. (2011) evaluated the performance of Tris and powdered coconut water (ACP109c) diluents on the cryopreservation of epididymal sperm derived from $D$. leporina, wherein the samples were centrifuged, and extended in the same diluents in addition to egg yolk (20\%) and glycerol $(6 \%)$. After sperm cryopreservation and thawing, they observed that $26.5 \pm 2.6 \%$ were motile sperm with $2.6 \pm 0.2$ vigor in the ACP-109c group, which was significantly better than $9.7 \pm 2.6 \%$ motile sperm with $1.2 \pm 0.3$ vigor found in the Tris group. They verified that ACP-109c would be the most suitable diluent for processing and cryopreservation of these cells. Subsequently, the same group, studying the interactions between straw size $(0.25$ or $0.50 \mathrm{~mL})$ and thawing rates $\left(37^{\circ} \mathrm{C}\right.$ for $60 \mathrm{~s}$ or $70^{\circ} \mathrm{C}$ for $8 \mathrm{~s}$ ) for epididymal sperm, demonstrated that epididymal sperm of agouti could be efficiently cryopreserved in both $0.25 \mathrm{~mL}$ or $0.50 \mathrm{~mL}$ straws and thawing should be conducted at $37^{\circ} \mathrm{C}$ for $60 \mathrm{~s}$. The use of $0.25 \mathrm{~mL}$ and $0.5 \mathrm{~mL}$ straws thawed at $37^{\circ} \mathrm{C}$ for $60 \mathrm{~s}$ provided a value of $26.6 \%$ and $18.4 \%$ for sperm motility, respectively (Silva et al., 2012).

Furthermore, for cryoprotectants (CPAs), Castelo et al. (2015), using glycerol, dimethylsufoxide (DMSO), and dimethylformamide (DMF) at 3\% and 6\% concentrations, demonstrated that $6 \%$ glycerol was the most appropriate for cryopreservation of spermatozoa of $D$. leporina compared to that by other CPAs, in which it was possible to recover spermatozoa with a mean motility of $39.5 \pm 4.6 \%$ after thawing

Through electroejaculation, Mollineau et al. (2010a) diluted the ejaculates of D. leporina in ultrahigh-temperature (UHT) milk, unpasteurized coconut water, or pasteurized coconut water under refrigeration at $5^{\circ} \mathrm{C}$. After $24 \mathrm{~h}$ of storage, best results were achieved in the samples diluted in UHT milk, with sperm motility values of $59.5 \pm 7.75 \%$. For cryopreservation, however, only $12.5 \%$ of sperms presenting progressive motility were obtained after thawing at $30^{\circ} \mathrm{C}$ for $20 \mathrm{~s}$ using the same milk diluent (Mollineau et al., 2010b). Recently, Castelo et al. (2016) cryopreserved samples derived via electroejaculation conducted on $D$. leporina. They demonstrated that the use of an extender containing ACP- $109 \mathrm{c}$ with $20 \%$ egg yolk and $6 \%$ glycerol was able to yield $31.2 \%$ motile sperms after thawing.

Recovery of epididymal sperm appears as the most viable alternative for male gamete retrieval in this species to use viable sperms for the development of cryopreservation procedures. However, in agouti, obtaining sperm by electroejaculation is still a challenge, and based on these findings, we can infer that the main obstacle for the improvement of ARTs in male agouti is the low efficiency of electroejaculation protocols. Standardizing these protocols requires studying factors that may affect the success of cryopreservation that are appropriate to the inherent characteristics of each species. In addition to the type of CPAs, there is need for consideration of important factors such as their concentration and effects on sperm fertilizing ability.

Despite the advances already achieved (Tab. 3 ), the need for further studies is highlighted, with the objective of improving the protocols of electroejaculation with respect to time, interval between series, and anesthetic planes as demonstrated for other domestic and wild species. In the cryopreservation protocols, incorporation of new additives as detergents based on sodium dodecyl sulfate (SDS) and new CPAs, such as Aloe vera extract, may improve the quality and longevity of the sperm cell. To our knowledge, cryopreservation of testicular tissue has not been reported, which would represent a method for the conservation of the biodiversity of this species with future application in in vitro culture and optimization of diverse reproductive biotechniques. 
Table 2. Values (Mean \pm SEM) for the agoutis' (D. Leporina) sperm parameters obtained by electroejaculation and retrograde epididymal washing

\begin{tabular}{lcc}
\hline \multicolumn{1}{c}{ Sperm parameters } & Eletroejaculation & Retrograde epididymal washing \\
\hline Volume $(\mathrm{mL})$ & $0.6 \pm 0.1$ & $1.65 \pm 0.22$ \\
Sperm concentration $\left(\times 10^{9}\right.$ sperm $\left./ \mathrm{mL}\right)$ & $307.5 \pm 69.6$ & $822.5 \pm 85.0$ \\
Sperm motility $(\%)$ & $93.7 \pm 4.7$ & $96.2 \pm 2.4$ \\
Vigor $(0-5)$ & $5.0 \pm 0.0$ & $5.0 \pm 0.0$ \\
Membrane integrity $(\%)$ & $74.0 \pm 4.0$ & $90.5 \pm 2.1$ \\
Osmotic response $(\%)$ & $66.2 \pm 4.0$ & $79.7 \pm 2.6$ \\
Sperm morphology $(\%)$ & $77.2 \pm 4.1$ & $80.7 \pm 8.1$ \\
\hline
\end{tabular}

Source: Castelo (2015).

Table 3. State of the art of assisted reproductive techniques (ARTs) applied for agoutis' (Dasyprocta spp.) males. Species ART Source

$\begin{array}{lll}\begin{array}{l}\text { Dasyprocta azarae } \\ \text { Dasyprocta leporina }\end{array} & \text { Eletroejaculation } & \text { Martinez et al., (2013) } \\ & \text { Retrograde epididymal washing } & \text { Silva } \text { et al., (2011) } \\ & \text { Eletroejaculation } & \text { Castelo } \text { et al., (2015) } \\ & & \text { Mollineau } \text { et al., (2008; 2010a) } \\ & \text { Refrigeration of sperm } & \text { Castelo } \text { et al., }(2016) \\ & \text { Mollineau } \text { et al., }(2010 \mathrm{a} ; 2010 \mathrm{~b}) \\ & \text { Crypreservation of epididymal spermatozoa } \text { et } .,(2011 ; 2012)\end{array}$

\section{Reproductive morphophysiological aspects of female agouti}

The ovaries (Fig. 4) of the agouti are located in the sublumbar region, caudally to the kidney, in the abdominal cavity presenting an ellipsoid or oval shape, flattened dorsoventrally (Almeida et al., 2003). According to the morphometric data, the right ovary weighs an average of $0.082 \mathrm{~g}$, with a length of $0.83 \mathrm{~cm}$, width of $0.49 \mathrm{~cm}$, and thickness of $0.24 \mathrm{~cm}$; whereas, the left ovary weighs $0.058 \mathrm{~g}$, with a length of $0.74 \mathrm{~cm}$, width of $0.45 \mathrm{~cm}$, and thickness of $0.23 \mathrm{~cm}$ (Almeida et al., 2003). Histologically, the ovaries are covered by a simple cubic epithelium on a layer of connective tissue rich in fibers, and a high volume of accessory corpora lutea are described in this species (Weir, 1974). The ovaries are light yellow in color, with a smooth outer surface and small translucent areas, suggestive of the presence of follicles in different categories (Santos et al., 2018).

The follicle, a morphofunctional unit of the ovary, presents dimensions varying between the follicular classes (Fig. 5). The primordial follicle is $18.62 \pm 3.40 \mu \mathrm{m}$ in diameter, with oocyte of $12.28 \pm 2.37$ $\mu \mathrm{m}$ and nucleus of $6.10 \pm 0.93 \mu \mathrm{m}$; the primary follicle is $23.75 \pm 5.70 \mu \mathrm{m}$ in length, oocyte of $14.22 \pm 3.00 \mu \mathrm{m}$, and nucleus of $6.70 \pm 1.24 \mu \mathrm{m}$; and the secondary follicle is $88.55 \pm 17.61 \mu \mathrm{m}$ in length, oocyte of $52.85 \pm 17.56 \mu \mathrm{m}$, and nucleus of $22.33 \pm 17.61 \mu \mathrm{m}$ (Santos et al., 2018). In addition, the follicular population in D. leporina is estimated at $4419.8 \pm$ 532.26 and $5397.52 \pm 574.91$ follicles in the right and left ovary, respectively. A high number of polyovular follicles, representing $7.51 \%$ of the follicles, are observed.
In general, for all females agouti, puberty is established at around the age of nine months; however, further information on the establishment of this event in different species of Dasyprocta is limited. The estrous cycle lasts for a mean period of $34.2 \pm 2.1$ days, with the existence of short cycles of only 12 days (Weir, 1971). However, in D. prymnolopha, Guimarães et al. (1997) conducted a study through vaginal cytology analyses and verified a mean duration of $30.69 \pm 4.65$ days for the estrous cycle, with variations between 19 and 40 days. Subsequently, they confirmed their results through hormonal measurements, performed twice a week, and determined the mean duration of the estrous cycle as $32.05 \pm 4.17$ days. There were no statistical differences in $17 \beta$-estradiol levels between the cycle phases. However, two peak periods of $17 \beta$ estradiol were observed, the first being in the metestrus $(75.88 \mathrm{pg} / \mathrm{mL})$ and the second during the proestrus $(77.26 \pm 20.71 \mathrm{pg} / \mathrm{mL})$. In the estrus, the initial progesterone concentration is low $(2.83 \pm 2.34 \mathrm{ng} / \mathrm{mL})$, but an increase in the progesterone level is observed at $24 \mathrm{~h}(9.02 \pm 2.34 \mathrm{ng} / \mathrm{mL})$ (Guimarães et al., 2011). For $D$. leporina, the estrous cycle was characterized as being polyestrous continuous with an average duration of 28 days, ranging from 24 to 31 days. Ultrasound analysis revealed no differences in ovarian morphology during the different phases of the estrous cycle. Follicles during the estrogenic phases (proestrus and estrus) were identified with an average diameter of $1 \pm 0.5 \mathrm{~mm}$. In only $12.5 \%$ of luteal phases, corpora lutea, measuring $1.4 \pm 0.9 \mathrm{~mm}$, were identified (Campos et al., 2015). The females of these species have a vaginal occlusion membrane, the perineum or operculum, the presence of which enables identification of the estrous phase, as observed in D. prymnolopha (Weir et al., 1974), and 
which opens only during the estrous cycle and parturition.

Overall, for all the agouti species, there are few studies on the reproductive morphology and physiology.
However, extensive knowledge on the female reproduction is important for the application of auxiliary reproductive biotechniques for its conservation and management.

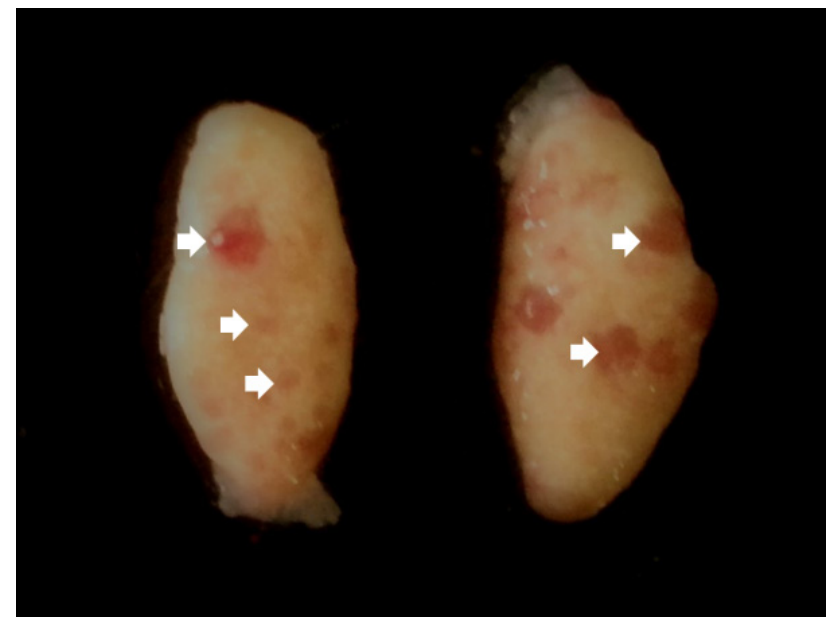

Figure 4. Ovary of the species Dasyprocyta leporina, with follicles at various stages of development (white arrows).
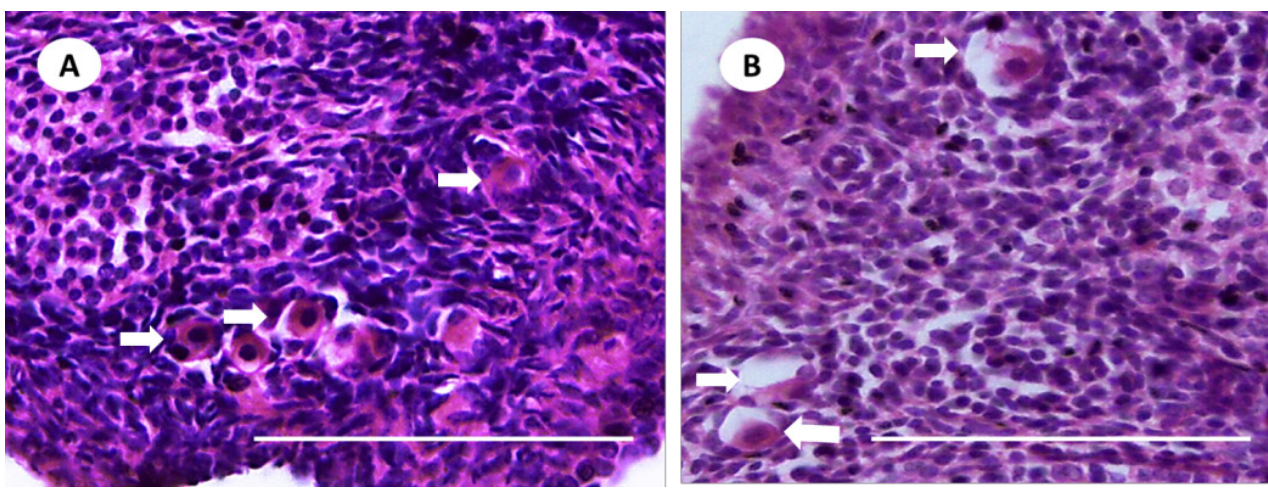

Figure 5. Photomicrographs of agouti (Dasyprocta leporina) ovarian sections. (A) Aggregates of primordial follicles displaying an oocyte surrounded by one layer of flattened cells (white arrows). (B) Degenerated follicles displaying oocyte cytoplasm retraction and disorganization of granulosa cells (white arrows).

\section{Gestation physiology and monitoring}

Kleiman et al. (1979) observed that for agouti, an average gestation period was 112 days, which varied among the 13 existing species. The occurrence of postpartum estrus has been reported in agouti and occurs between 18 and 20 days (Weir, 1971). The placenta is lobulate, monohemochorial, and is connected to the uterus through the mesoplacenta (Rodrigues et al., 2003).

Sousa et al. (2012) performed multifrequency sonography (5-7.5 $\mathrm{MHz})$ using a microconvex transducer to observe the characteristics related to the pregnancy age of the agouti $D$. prymnolopha. The first uterine morphological changes were observed on day 9 as an anechoic spherical structure, with slightly hyperechoic margins, and gestational sac was observed at only around 76 days after mating. In a recent study with the same species, B-mode ultrasonography associated with Doppler allowed the evaluation of the vascular network and determination of the reference values for blood flow necessary to maintain fetal viability at different gestational ages (Sousa et al., 2017). In addition, morphogenetic analysis of the fetuses of $D$. leporina from 30 to 100 days revealed stages of embryonic and fetal development (Oliveira et al., 2017), demonstrating the progress of speciesoriented studies.

\section{ART applied to female agouti}

Understanding the estrous cycle of a species is essential for the development of ART (Durrant, 2009). High variability among wild species, duration of the estrous period, and difficulty in determining the exact time of ovulation led to the development of useful methods for monitoring the estrous cycle (Pimentel et al., 2014). 
In a study conducted on animals bred in the Caatinga biome, it was possible to characterize the estrous cycle of $D$. leporina by means of exfoliative vaginal cytology (Fig. 6) and ultrasonography. Vaginal cytology revealed the predominance of superficial cells in the stages of proestrus and estrus, followed by intermediate cells in the metaestrus, thereby allowing the distinction of the follicular and luteal phases (Campos et al., 2015). Similar cytological findings have also been reported for D. prymnolopha (Guimarães et al., 1997). Additionally, the external genitalia of $D$. leporina presented changes related to the typical signs of the estrous phase, such as the opening of vulvar lips with the presence of mucous secretion. Such changes coincided with the presence of an ovarian follicle (with an average diameter of $1 \pm 0.5 \mathrm{~mm}$, varying from 0.4 to $1.6 \mathrm{~mm}$ ) as observed by ultrasonography, with the predominance of superficial cells (Campos et al., 2015). Furthermore, ultrasonography revealed that there were no differences in ovarian morphology during the different phases of the estrous cycle, but it was possible to observe follicles in the follicular phases and corpora lutea, measuring $1.4 \pm 0.9 \mathrm{~mm}$, in the luteal phases (Campos et al., 2015). The results of ovarian morphometry detected by ultrasonography in the different phases of the estrous cycle in $D$. leporina were similar to those observed in black agouti (D. fuliginosa) (Mayor et al., 2011).

The cycles of female $D$. leporina were confirmed by blood hormonal measurements. Females were monitored throughout their estrous cycle, and estrogen $\left(\mathrm{E}_{2}\right)$ and progesterone $\left(\mathrm{P}_{4}\right)$ concentrations were determined at all stages by enzyme linked immunosorbent assay (ELISA). $E_{2}$ levels were 1212$3500 \mathrm{pg} / \mathrm{mL}$, with the peak value coinciding with the observed estrus. However, two additional peak values for $E_{2}$, one in the metaestrus and one in proestrus were also recorded. The concentrations of $\mathrm{P}_{4}$ reached a maximum value of $4.23 \mathrm{ng} / \mathrm{mL}$, and the increase in $\mathrm{P}_{4}$ occurred immediately after the second peak of $E_{2}$ in metaestrus, with the highest concentrations of $\mathrm{P}_{4}$ recorded in diestrus (Singh et al., 2016). However, in agouti, there are still few reports on monitoring of the estrous cycle through hormonal dosages.

The induction of estrus was reported for $D$. leporina, in which the hormonal protocols consisting of peritoneal administration of cloprostenol $(5 \mu \mathrm{g})$ alone or in combination with a gonadotropin-releasing hormone $(\mathrm{GnRH})$ analog $(30 \mu \mathrm{g})$ were compared. Using only cloprostenol, estrus induction was verified in only $40 \%$ of females that manifested estrus signs and presented estrogen peak at 3 and 6 days after drug administration. However, combination therapy with both the hormones yielded estrus induction in $60 \%$ of animals, but $40 \%$ of the animals manifested estrus at day 4 and $20 \%$ at day 10 day after drug administration (Peixoto et al., 2018). Although these protocols promoted estrus induction, the authors do not suggest this method as an effective means to achieve synchronization of estrus induction in D. leporina.
Parallel to these studies, cryopreservation of ovarian tissue has been developed with the aim of creating biobanks using the female germplasm. For $D$. leporina, preservation of up to $64 \%$ preantral follicles (PFs) was achieved using a conventional freezing method with different CPAs, such as DMSO, ethylene glycol (EG), and propanediol $(\mathrm{PROH})$ at $1.5 \mathrm{M}$. However, transmission electron microscopy analyses revealed that $\mathrm{PROH}$ provided the most efficient preservation of the ovarian tissue ultrastructure and thus, is suggested for use in agouti (Wanderley et al., 2012).

Another study performed a cryopreservation protocol based on solid surface vitrification of $D$. leporina ovarian tissue. It was verified that regardless of the CPA used (DMSO 3.0 M or 6.0 M, EG 3.0 M or 6.0 $\mathrm{M}$, and a combination of both agents), it was possible to preserve up to $70 \%$ of the follicular morphology. Moreover, DNA fragmentation was not observed in any of the groups exhibiting preserved follicular viability similar to that observed in the non-vitrified group (Praxedes, 2017).

In addition, the first ovarian tissue xenograft of non-vitrified and vitrified fragments of $D$. leporina was reported in 2017. Grafts are tools that can be used to measure the survival of tissue after cryopreservation and, in case of ovarian grafts, to obtain knowledge regarding follicular dynamics of various species. Praxedes et al. (2018) using a combination of DMSO and EG in immunosuppressed mice for both the nonvitrified (80\%) and vitrified (16\%) groups observed that ovarian activity was recovered after $20.6 \pm 8.6$ days of xenografting. The recovery of ovarian activity was characterized by the presence of typical signs of proestrus and estrus, associated with the increase in $E_{2}$ concentrations in recipient severe combined immunodeficiency (SCID) mice. Microscopically, primordial, primary, transitional, and secondary follicles, corpora lutea, and hemorrhagic body were observed in the grafts exhibiting normal morphology for the species studied (Praxedes et al., 2017).

Even with the advances in studies on reproductive biotechniques (Tab. 4) aimed at conserving the genetic material of female agouti, it is necessary to improve the existing protocols that allow better rates of preservation of morphological integrity and viability of follicles before they become atresic. These studies are needed not only to safeguard genetic material, but also for use in other biotechniques, such as in vitro fertilization and cloning.

However, in wild animals, cryopreservation of female gametes and conditions necessary for the complete development of in vitro PFs are still not well established. Thus, many studies are aimed at developing and adapting efficient in vitro culture systems to evaluate the effect of different substances (gonadotropins and intra-ovarian factors) on initial oocyte development for obtaining information about the mechanisms involved in folliculogenesis. 


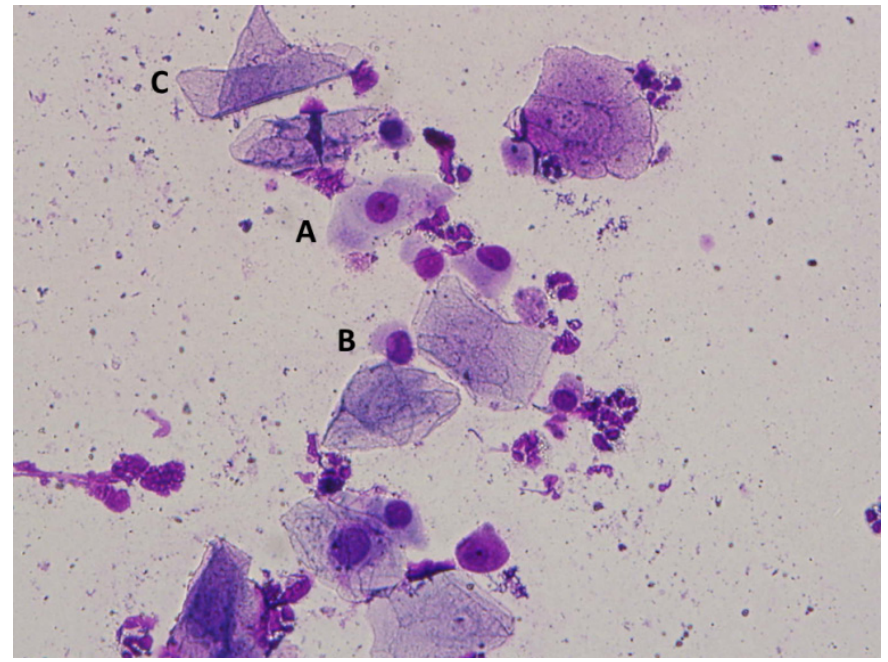

Figure 6. Exfoliative vaginal cytology of agouti (Dasyprocta leporina). (A) intermediate cell; (B) parabasal cells; (C) surface cell.

Table 4. State of the art of assisted reproductive techniques (ARTs) applied for agoutis' (Dasyprocta spp.) females.

\begin{tabular}{lll}
\hline Species & ARTs & Source \\
\hline Dasyprocta leporina & Monitoring the estrous cycle & Campos et al., (2015) \\
& Gestational monitoring & Singh et al., (2016) \\
& & Sousa et al., (2017) \\
& Induction of estrus & Oliveira et al., (2017) \\
& Cryopreservation of ovarian tissue & Peixoto (2016) \\
& & Wanderley et al., (2012) \\
& Xenograft of fresh and vitrified ovarian tissue & Praxedes (2017) \\
Dasyprocta prymnolopha & Monitoring the estrous cycle & Guimarães et al., (1997) \\
& Gestational monitoring & Souza et al., (2012) \\
\hline
\end{tabular}

\section{Conservation and culture of agouti somatic tissue}

The establishment of somatic cryobanks has been suggested as an important tool for conservation of endangered (Loi et al., 2001 or zootechnically valuable species (Loi et al., 2001, Pereira et al., 2013), as an alternative to the conservation of animal biodiversity. It allows the optimization of other reproductive biotechniques in association with nuclear somatic cell transfer (SCNT, also known as cloning). In agouti, studies focused on the formation of biobanks derived from somatic tissue are still nascent and little is known about the use of this genetic source.

Thus, aimed at the formation of germplasm banks, a study used peripheral ear tissue of $D$. leporina and analyzed different techniques of vitrification (solid surface and conventional vitrification) for the conservation of somatic samples. Vitrification consisted of exposing the fragments in DMEM medium supplemented with 20\% DMSO, 20\% EG, $0.25 \mathrm{M}$ sucrose, and $10 \%$ fetal bovine serum for $5 \mathrm{~min}$. Based on histological analyses, it was observed that solid surface vitrification better preserved the somatic tissue (Costa et al., 2015).

Thus, the interest in various tissue sources is primarily based on the possibility of using different cell types as a nucleus donor cell in SCNT (Arat et al., 2011). Therefore, samples derived from the skin are widely used for tissue preservation in addition to the formation of cryobanks, reproduction by SCNT, and pluripotency studies (Borges et al., 2015).

\section{Final Considerations}

The Dasyprocta spp., besides being considered an alternative source of protein, has great potential as an experimental model for studying reproductive biotechniques and the formation of germplasm banks. However, it presents distinct limitations. The evolution and adaptation of different protocols to the characteristics of each species is not characterized. Moreover, it should be noted that very little is known about the morphophysiological characteristics of male and female agouti. This knowledge is essential for future application in sustainable production systems as well as for the development and improvement of protocols that guarantee the maintenance of cellular viability and allow the conservation, multiplication, and preservation of the biodiversity of these species and other related species. 


\section{References}

Almeida MM, Carvalho MAM, Cavalcante Filho MF, Miglino MA, Menezes DJA. 2003. Estudo morfológico e morfométrico do ovário de cutias (Dasyprocta aguti, Linnaeus, 1766). Braz J Vet Res Anim Sci, 40:55-62.

Arat S, Caputcu AT, Akkoc T, Pabuccuoglu S, Sagirkaya H, Cirit U, Nak D. 2011. Using cell banks as a tool in conservation programmes of native domestic breeds: the production of the first cloned Anatolian Grey cattle. Reprod Fertil Dev, 23:1012-1023.

Arroyo MAM, Oliveira MF, Santos PRS, Assis Neto AC. 2014. Ultrastructure of the epididymis and vas deferens of agoutis at different stages of sexual development. Anim Reprod Sci, 149:273-280.

Arroyo MAM, Silva FFS, Santos PRS, Silva AR, Oliveira MF, Assis Neto AC. 2017. Ultrastructure of spermatogenesis and spermatozoa in agoutis during sexual development. Reprod Fertil and Dev, 29(2):383393.

Assis-Neto AC, Carvalho MAM, Melo MIV, Miglino MA, Oliveira MF, Almeida MM. 2003a. Aspectos biométricos do desenvolvimento testicular e corporal de cutias (Dasyprocta agouti) criadas em cativeiros. Braz J Vet Res Anim Sci, 40:154-160.

Assis-Neto AC, Melo MIV, Carvalho MAM, Miglino MA, Oliveira MF, Menezes DJA, Papa PC, Kfoury Júnior JR. 2003b. Análise quantitativa do estabelecimento da espermatogênese em cutias (Dasyprocta aguti) criadas em cativeiro. Braz J Vet Res Anim Sci, 40:180-184.

Barbosa DFSF, Silva JBA, Oliveira MF, Araujo SAC. 2010. Avaliação qualitativa de carnes de catetos (Tayassu tajacu, LINNAEUS, 1758) e cutias (Dasyprocta aguti, Linnaeus, 1758) Criados em cativeiro. Dissertação Mestrado. - Universidade Federal Rural do Semi-Árido, Mossoró, RN.

Bonaudo T, Le Pendu Y, Faure JF, Quantz D. 2005. The effects of deforestation on wildlife along the transamazon highway. Eur J Wildlife Res, 51(3):199-206. Borges AA, Queiroz Neta LQ, Santos MVO, Santos MLT, Lima GL, Oliveira MF, Silva AR, Pereira AF. 2015. Isolation of somatic cell derived from ear tissue of collared peccary (Pecari tajacu Linnaeus, 1758) submitted to different vitrification techniques. Anim Reprod, 12(1):842.

Campos LB, Peixoto GCX, Lima GL, Castelo TS, Souza ALP, Oliveira MF, Silva AR. 2015 Monitoramento do ciclo estral de cutias (Dasyprocta leporina Lichtenstein, 1823) através de citologia esfoliativa vaginal e ultrassonografia. Pesq Vet Bras, 35:188-192.

Carvalho MAM, Machado Júnior AAN, Silva RAB, Conde Júnior AM, Menezes DJA, Righi DA. 2008 Arterial supply for the penis in Agoutis (Dasyprocta prymnolopha, Wagler, 1831). Anat Histol Embryol, 37:60- 62

Castelo TS. 2015. Obtenção e conservação de espermatozoides de cutia (dasyprocta leporina linneaus, 1753) do Semiárido brasileiro. Tese doutorado. Programa de Pós Graduação em Biotecnologia da Rede Nordeste de Biotecnologia (RENORBIO), Natal, RN. $134 f$.

Castelo TS, Silva AM, Bezerra LG, Costa CY, Lago AE, Bezerra JA, Campos LB, Praxedes EC, Silva AR. 2015. Comparison among different cryoprotectants for cryopreservation of epididymal sperm from agouti (Dasyprocta leporina). Cryobiology, 71:442-447.

Castelo TS, Souza ALP, Lima GL, Peixoto GCX, Campos LB, Oliveira MF, Silva AR. 2016. Interactions among different devices and electrical stimulus on the electroejaculation of captive agoutis (Dasyprocta leporina). Reprod Domest Anim, 50:492-496.

Comizzoli P, Mermillod P, Cognie Y, Chai N, Legendre X, Mauge R. 2001. Succesful in vitro production of embryos in the red deer (Cervus elaphus) and the sika deer (Cervus nippon). Theriogenology, 55:649-659.

Costa CAS, Borges AA, Santos MVO, Queiroz Neta LB, Santos MLT, Franca PHF, Oliveira MF, Silva AR, Pereira AF. 2015. Aplicação da vitrificação para fins de conservação de tecido somático de cutias (Dasyprocta leporina). In: Seminário de Iniciação Científica da UFERSA, 21, 2015, Mossoró, RN. Anais... Mossoró: UFERSA.

Costa GMJ, Leal MC, Ferreira AC, Guimarães DA, França LR. 2010. Duration of spermatogenesis and spermatogenic efficiency in large neotropical rodent species: the Agouti (Dasyprocta leporina) and Paca (Agouti paca). J Androl, 31:489-499.

Costa PM, Martins CF. 2008. Conservação de recursos genéticos animais através de biotécnicas de reprodução. Universitas Ciências da Saúde, 6:39-55.

Deutsch LA, Puglia LRR. 1988. Paca, p.45-50. In: Deutsch LA and Puglia LRR (ed.), Os Animais Silvestres: Proteção, doenças e manejo. Editora Globo, Rio de Janeiro, 191p.

Durrant BS. 2009. The importance and potential of artificial insemination in CANDES (companion animals, non-domestic, endangered species). Theriogenology, 71:113-122.

Emmons LH, Feer F. 1997. Neotropical rainforest mammals: a Field Guide. (2 ed). Chicago: University of Chicago Press. 307p

Ferraz MS, Conde Junior AM, Fortes EAM, Almeida HM, Rodriguez NM, Silva AR, Carvalho MAM. 2009. Caracterização morfométrica de espermatozóides epididimários de cutias (Dasyprocta aguti) criadas em cativeiro. In: Congresso Brasileiro de Reprodução Animal, 18, 2009, Belo Horizonte, MG. Anais... Belo Horizonte: CBRA. (CD-ROM), p.291. Resumo.

Ferraz MS, Menezes DJA, Pessoa GT, Cabral RM, Illera MJ, Silva AR. 2011. Collection and evaluation of epididymal sperm in captiveagoutis (Dasyprocta aguti), Theriogenology, 75:459.

Forget PM, Milleron T. 1991. Evidence for secondary seed dispersal by rodents in Panama. Oecologia, 87:596-599.

Goovaerts IGF, Hoflanck GG, Van Soom A, Dewulf J, Nichi M, Kruif A, Bols PE. 2006. Evaluation of epididymal semen quality using the Hamilton-Thorne analyser indicates variation between the two caudae epididymides of the same bull. Theriogenology, 66:323330. 
Guimarães DA, Moreira D, Vale WG. 1997. Determinação do ciclo reprodutivo da cutia (Dasyprocta prymnolopha) através do diagnóstico colpocitológico. Acta Amaz, 27(1):55-64.

Guimarães DAA, Ramos RSL, Garcia GW, Ohashi OM. 2009. The stimulatory effect of male agouti (Dasyprocta prymnolopha) on the onset of female puberty. Acta Amaz, 39(4):759-762.

Guimarães DA, Ramos RL, Ohashi OM, Garcia GW, Vale WG. 2011. Plasma concentration of progesterone and $17 \beta$-estradiol of blackrumped agouti (Dasyprocta prymnolopha) during the 505 estrous cycle. Revta Bras Tróp, 59(1):29-35.

Henry O. 1999. Frugivory and the importance of seeds in the diet of the orange-rumped agouti (Dasyprocta leporina). J Trop Ecol, 15:291-300.

Hosken FM, Silveira AC. 2001. Criação de cutias. Viçosa, MG: Aprenda fácil, 4:21-22.

IUCN Red List Categories and Criteria, Version 3.1. IUCN, Gland, Switzerland and Cambridge, UK. Available on: www.iucnredlist.org. Accessed on: January 26th 2018.

Kleiman DG, Eisenberg JF, Maliniak E. 1979. Reproductive parameters and productivity of caviomorph rodents. In: Vertebrate ecology in the northern Neotropics. Eisenberg JE (ed.). Smithsonian Institution Press, Washington, D.C. pp.173-183.

Lange RR, Schimidt EMS. 2007. Tratado de animais selvagens. Roca: São Paulo, Brasil, p.476.

Lima, JFS. 2000. Diversidade cariológica de roedores de pequeno porte do Estado do Tocantins, Brasil. Tese (Doutorado) - Universidade Estadual Paulista, Instituto de Biociências de Rio Claro, SP, Brasil. 183f.

Loi P, Ptak G, Barboni B, Fulka J, Cappai P, Clinton M. 2001. Genetic rescue of an endangered mammal by cross-species nuclear transfer using postmortem somatic cells. [Nat Biotechnol, 19:962-964.

Lopes JB, Cavalcante RR, Almeida MM, Carvalho MAM, Moura SG, Filho LAD, Conceição WLF. 2004. Desempenho de Cutias (Dasyprocta prymnolopha) Criadas em Cativeiro do Nascimento até o Desmame em Teresina, Piauí. Rev Bras Zoo, 33(6):2318-2322.

Martinez AC, Oliveira FS, Abreu CO, Martins LL, Pauloni AP, Moreira N. 2013. Colheita de semên por eletroejaculação em cutia-parda (Dasyprocta azarae). Pesq Vet Bras, 33(1):86-88.

Martinez-Pastor F, Garcia-Macias V, Alvarez M, Chamorro C, Herraez P, Paz P, Anel L. 2006. Comparison of two methods for obtaining spermatozoa from the caudaepidydimis of Iberian red deer. Theriogenology, 65:471-485.

Mayor P, Bodmer RE, And Lopez-Bejar M. 2011. Functional anatomy of the female genital organs of the wild black agouti (Dasyprocta fuliginosa) female in the Peruvian Amazon. Anim Reprod Sci, 123:249-257.

Menezes DJA, Carvalho MAM, Assis-Neto AC, Oliveira MF, Farias EC, Miglino MA, Medeiros GX. 2003. Morfologia dos órgãos genitais externos do macho de cutia (Dasyprocta aguti, Linnaeus, 1766). Braz J Vet Res Anim Sci, 40(2):148-153.

Mollineau WM, Adogwa A, Jasper N, Young K,
Garcia G. 2006. The gross anatomy of the male reproductive system of a neotropical rodent: the agouti (Dasyprocta leporina). Anat Histol Embryo, 35:47-52.

Mollineau WM, Adogwa AO, Garcia GW. 2008. A preliminary tech-nique for electro-ejaculation of agouti (Dasyprocta leporina). Anim Reprod Sci, 7:92-108.

Mollineau WM, Adogwa AO, Garcia GW. 2010a. Improving the Efficiency of the Preliminary Electroejaculation Technique Developed for Semen Collection from the Agouti (Dasyprocta leporina). $J$ Zoo and Wildlife Medic, 41:633-637.

Mollineau WM, Adogwa AO, Garcia GW. 2010 b. Liquid and frozen storage of agouti (Dasyprocta leporina) semen extended with UHT Milk, unpasteurized coconut water, and pasteurized coco-nut water. Vet Med Int, 2011:1-6.

Mollineau WM, Sampson T, Adogwa AO, Garcia GW. 2012. Anatomical Stages of Penile Erection in the Agouti (Dasyprocta leporina) Induced by ElectroEjaculation. Anat Histol Embryol, 41:392-394.

Monteiro GA, Papa FO, Zahn FS, Della JA Jr, Melo CM, Maziero RR, Avanzi BR, Alvarenga MA, Guasti PN. 2011. Cryopreservation and fertility of ejaculated and epididymal stallion sperm. Anim Reprod Sci, 127:197-201.

Oliveira FS, Martins LL, Canola JC, Oliveira PT, Pécora JD, Pauloni AP. 2012. Macroscopic description of teeth of Azarae agouti (Dasyprocta azarae). Pesq Vet Bras, 32(1):93-95.

Oliveira GB, Araújo Júnior HN, Silva Costa H, Silva AR, Moura CEB, Oliveira Rocha HA, Miglino MA, Oliveira MF. 2017. Post implantation development of red-rumped agouti (Dasyprocta leporina Linnaeus, 1758). Anim Reprod Sci, 182:35-47.

Pachaly JR, Lange RR, Margarido TCC. 1999. Punção venosa em cutias (Dasyprocta sp.). Hora Vet, 18A:62-64.

Paula TAR, Walker NJ. 2012. Reproductive morphology and physiology of the male capybara. In: Moreira JR; Ferraz, KMPMB, Herrera EA, MacDonald DW. Capybara: Biology, use and Conservation of Exceptional Neotropical Species. Springer, New York, 109-115.

Peixoto GCX, Maia KM, Almeida LM, Campos LB, Oliveira GB, Oliveira MF, Brito AB, Domingues SFS, Silva AR. 2018. Indução do estro em cutias (Dasyprocta Leporina) Utilizando protocolos a base de prostaglandina isolada ou em associação com análogo de GnRH. Arq Bras Med Vet Zoo, 70:806-814.

Pereira AF, Feltrin C, Almeida KC, Carneiro IS, Avelara SRG, Alcântara Neto AS, Sousa FC, Melo CHS, Moura RR, Teixeiraa DIA, Bertolini LR, Freitas VJF, Bertolini M. 2013. Analysis of factors contributing to the efficiency of the in vitro production of transgenic goat embryos (Capra hircus) by handmade cloning (HMC). Small Rumin Res, 109(2):163-172.

Praxedes ECG. 2017. Conservação de tecido ovariano de cutias (Dasyprocta leporina Lichtenstein, 1823) criadas em cativeiro no semi-árido nordestino. Dissertação Mestrado. Universidade Federal Rural do Semi-Árido, Mossoró, RN. 105f. 
Praxedes ECG, Lima GL, Bezerra LGP, Santos FA, Bezerra MB, Guerreiro DD, Rodrigues APR, Domingues SFS, Silva AR. 2018. Development of fresh and vitrified agouti ovarian tissue after xenografting to ovariectomised severe combined immunodeficiency (SCID) mice. Reprod Fertil Dev, 30 (3):459-468.

Ramos RSL, Vale WG, Assis FL. 2003. Karyotypic analysis in species of the genus Dasyprocta (Rodentia: Dasyproctidae) found in Brazilian Amazon. An Acad Bras Cienc, 75(1):55-69.

Ribeiro EEA, Batista MCS, Carvalho MAM, Silva JAL. 2008. Níveis iônicos e enzimáticos de cutias (Dasyprocta sp.) hígidas, criadas em cativeiro, influência do sexo e da idade. Arq Bras Med Vet Zootec, 70:651-655.

Rodrigues RF, Miglino MA, Ferraz RHS, MoraisPinto L. 2003. Placentação em cutias (Dasyprocta aguti, Carleton MD): aspectos morfológicos. Braz J Vet Res Anim Sci, 40:133-137.

Roopchand A. 2002 Wildlife and the Oil Industry: Catshill Reserve a Case Study. M.Sc. Student project, The Department of Food Production, Faculty of Science and Agriculture, University of the West Indies, St Augustine, Trinidad and Tobago.

Santos CR, Filho HO, Barbosa OR, Cardozo RM, Araujo DN, Fornari DC, Guaragni M, Fregadolli RM. 2005. Etologia de capivaras (Hydrochaerism hydrochaeris L. 1766) jovens semiconfinadas no Norte do Estado do Paraná. Acta Sci Anim Sci, 1(27):163-169.

Santos EAA, Lima GL, Praxedes ECG, Silva AM, Maia KM, Oliveira MF, Rodrigues APR, Silva AR. 2018. Estimation, Morphometry and Ultrastructure of Ovarian Preantral Follicle Population in Agout (Dasyprocta leporina). Pesq Vet Bras, 38(1):175-182.

Silva DC, Fagundes NC, Teixeira FB, Penha NE, Santana LN, Mendes-Oliveira AC, Lima RR. 2013. Anatomical and histological characteristics of teeth in agouti (Dasyprocta prymnolopha Wagler, 1831). Pesq Vet Brasil, 33:51-57.

Silva MA, Peixoto GCX, Santos EAA, Castelo TS, Oliveira MF, Silva AR. 2011. Recovery and cryopreservation of epididymal sperm from agouti (Dasiprocta aguti) using powdered coconut water (ACP-109c) and Tris extenders. Theriogenology, 76:108-1089.

Silva MA, Peixoto GCX, Sousa PC, Bezerra FS, Bezerra AC, Silva AR. 2012. Interactions between straw size and thawing rates on the cryopreservation of agouti (Dasyprocta aguti) epididymal sperm. Reprod Domest Anim, 47:4-6.

Silva AR, Castelo TS, Lima GL, Peixoto GCX. 2010. Conservation of germplasm from wild animalsof the Caatinga biome. Acta Sci Anim Sci, 38:373-389.

Silva AR, Morato RG, Silva LDM. 2004. The potential for gamete recovery from nondomestic canids and felids. Anim Reprod Sci, 81:159-175.

Singh MD, Morris MJ, Guimaraes DA, Bourne G, Garcia, GW. 2016. Serological evaluation of ovarian steroids of red-rumped agouti (Dasyprocta leporina) during the estrous cycle phases. Anim Reprod Sci, 175:27-32.

Smythe, N. 1987. The paca (Cuniculus paca) as a dosmetic source of protein the Neotropical, Humid Lowlands. Appl Anim Behav Sci, 17:155-170.

Sousa F, Pessoa GT, Moura LS, Araújo JR, Rodrigues R, Barbosa M, Diniz AN, Souza AB, Silva EG, Lucena LU, Sanches MP, Silva-Filho OF, Guerra PC, Sousa JM, Neves WC, Alves FR. 2017. Organogenesis and foetal haemodynamics during the normal gestation of healthy black-rumped agoutis (Dasyprocta prymnolopha, Wagler, 1831) bred in captivity. Reprod Domest Anim, 52(1):60-66.

Sousa FCA, Alves FR, Fortes EAM, Ferraz MS, Machado Júnior AAN, Menezes DJA, Carvalho MAM. 2012. Pregnancy in Hystricomorpha: gestational age and embryonic fetal development of agouti (Dasyprocta prymnolopha Wagler, 1831) estimated by ultrasonography. Theriogenology, 78(6):1278-1285.

Souza PC, Ramos RSL, Guimarães DAA, Ferreira ACS, Bastos LV, Batista CR, Ohashi OM. 2003. Determinação da população folicular em cutias (Dasyprocta sp.) criadas em cativeiro. Rev Bras Reprod Anim, 27(2):286-287.

Wanderley LS, Luz HK, Faustino LR, Lima IM, Lopes CA, Silva AR, Báo SN, Campello CC, Rodrigues AP, Figueiredo JR. 2012. Ultrastructural features of agouti (Dasyprocta aguti) preantral follicles cryopreserved using dimethyl sulfoxide, ethylene glycol and propanediol. Theriogenology, 77(2):260-7.

Weir B. 1971. Some observations on reproduction in the female agouti (Dasyprocta aguti). J Reprod Fertil, 24:203-211.

Weir BJ, Rowlands JW. 1974. Functional anatomy of the hystricimorph ovary. Symp Zool Soc Lond, 34:303332 . 